\title{
URBAN TRANSPORT SECURITY: ANALYSIS OF TRANSIT CRIME IN OSOGBO, NIGERIA
}

\author{
Olorunfemi Ayodeji OLOJEDE* \\ Human Settlement Unit, Research Directorate, Mangosuthu University of Technology, Umlazi, Durban, South Africa \\ e-mail: olorunfemiolojede@ @mail.com, olojede.ayodeji@mut.ac.za
}

\begin{abstract}
The paper assesses transit crimes in Osogbo, Nigeria. Six political wards were selected across the residential areas of the town and a questionnaire was administered on 450 respondents. Data were analysed using percentages, the Relative Importance Index (RII) and Chi-Square tests. The study found that pickpocketing, armed robbery, and assault and battery were among common transit crimes in Osogbo, and that transit crime vulnerability varied by mode. A significant relationship was found between transit crime experience and socioeconomic characteristics. Poor policing, economic hardship, poor street system and the absence of CCTV topped the chart of causes of transit crimes. The commercial motorcycle was the least secure transport mode, while official vehicles were the most secure mode. Furthermore, security agencies were rated very low in transit security provision. Based on the findings, policy recommendations are proffered to enhance urban transport security in the city.
\end{abstract}

Key words: transit crime, transport security, okada, korope, Osogbo

$$
* \quad * \quad * \quad * \quad * \quad *
$$

\section{INTRODUCTION}

Urban transport security is arguably one of the most important factors that influence a lot of decisions about urban dwellers' travel behaviour. This is because in many cities of both developed and developing countries of the world, many intra-urban travellers have been victims of transit crime. Crimes such as rape, kidnapping and/or abduction, robbery, carjacking, car theft and even terrorism are perpetrated in transit. Indeed, at times, even fellow passengers perpetrate these criminal acts as not everyone that boards a vehicle is a genuine traveller. Experience has shown that criminals sometimes pose as travellers with the ulterior motive of victimising co-passengers. Little wonder then that security issues have been identified among the major challenges facing urban transport (Mercier-Handisyde, 2009).

Security issues in transit involve intrusion or attack, that may or may not include physical harm, that travellers are susceptible to in the course of their trip (Korver et al., 2012). There is also the place of safety in security considerations as security issues could degenerate into varying degrees of safety issues. For instance, the crime of unlawful driving practices can raise safety concerns, especially when accidents result. Besides, in an attempt to outsmart waylayers, the driver can end up involving the vehicle in an accident which then becomes a safety issue. Also, according 
to Omidiji and Ibitoye (2010), crime and criminalities contribute to road traffic crashes in public transportation. This is the main rationale for discussing urban transport safety and security issues jointly (Olojede et al., 2017). In many developing countries, studies on transport security have recorded a noticeable upsurge in the incidences of urban transit crime, particularly in the last two decades. In cities across most developing societies, the risk to lives and properties are becoming regular features on transport routes and terminals. Routine trips using public transit infrastructure can result in being mugged, robbed, or kidnapped (Ajayi and Ajayi, 2014). Harassments, murder, assaults, injuries, as well as loss of lives and properties, among other risks, are also identified by Odufuwa (2012a) as being among the persistently experienced transit crimes. It is such that crime incident is one of the greatest challenges facing public transport system in both developed and developing countries (Uittenbogaard, 2014).

Basically, transport insecurity is vulnerability to intentional criminal or antisocial acts suffered by those engaged in trip making. This could be property crime, violence (assault and threat), rape, sexual harassment, insult, murder, kidnapping and vandalism (Uittenbogaard, 2014). Also, according to Litman (2014), crime statistics may include violent crimes, all crimes against passengers and employees, or all transit-related crimes, a major portion of which involves trespassing, transit property vandalism and fare evasion. Extant literature and previous studies on transit crime have done justice to the exploration of the foregoing.

In a study by Uittenbogaard (2014) on crime in underground stations in Stockholm, Sweden, it was found that there were temporal dimensions to the occurrence of crime by type: theft was most common in the afternoon, vandalism in the evening, and violence at night. Furthermore, frequency of crime occurrence seems to be closely related with routine activities of individuals. Another important aspect of urban transport security has to do with drivers, as they have been found to be at a height of insecurity and vulnerability to transit crimes. Drivers in this context comprise the drivers of commercial and/or public, professional drivers (those who drive fleets and company vehicles), as well as private vehicles, chauffeurs inclusive. On a daily basis, they are exposed to such transit crimes as carjacking, car theft, robbery, aggression, abduction, and even murder. Cases abound of drivers being killed in the course of transit crime. Literature is replete with studies on drivers' security with the conclusion that they stand a high risk of transit crime (Couto et al., 2009, Klima, 2011; Lauer, 2005; Stanley, 2015; U. S. Department of Labor Occupational Safety and Health Administration, 2000).

Odufuwa (2012b) explored the gender perspective of criminal activities in public transport in Lagos metropolis, Nigeria. Among other things, the study addressed and discussed the question of how women are affected by insecure public transportation services as manifested in injuries, harassment, rape and other forms of assault experienced by women when using public transport. Ajayi and Ajayi (2014) also examined the trend analysis of crime incidences and crime vulnerability differentials on urban transport facilities in Ibadan, Nigeria. They analysed the temporal pattern of crime incidences across five selected bus stops and the variables that may likely determine the chances of becoming crime victims in the city. The research also examined the nature of criminal activities prevalent in the bus stations, analyzed the pattern of crime victim targeting in the selected bus stations, and made comparative analyses between the incidences and the nature of criminal activities in and around the stations. They found, among other things, that the risks of a passenger becoming a crime victim were heightened as a female. They also found that the time of the day when a travel is embarked on goes a long way in determining how secure the trip maker can be.

In their trans-regional study that traversed the three states of Kwara, Kogi and Ekiti in Nigeria, Omidiji and Ibitoye (2010) found, among other things, that transit crime (armed robbery, specifically) often leads to crashes. The study also revealed that criminals board vehicles along with unsuspecting passengers, at times disguising as clergymen who would start by preaching the gospel before suddenly unleashing havoc on passengers on board. Consequent upon this, commotion ensues leading to loss of vehicle control and ultimately resulting in road 
traffic crashes. In addition, it was found that mechanical deficiencies in vehicles, potholes and other poor road conditions, apart from causing road traffic crashes, also enhance the operations of the hoodlums on the highways.

Olojede, Daramola and Olufemi (2017) examined the safety and security of intra-urban transport in Ilesa, Nigeria. They found, among other things, that the vulnerability of trip makers to transit crime varied by mode. It was also found that owners of private cars were the most secure group of trip makers, while commercial motorcycle passengers and pedestrians were found to be the most vulnerable groups to transit crimes. Furthermore, the agencies responsible for traffic control and management were found to be wanting in some key functions with implications for urban transport safety and security. However, inasmuch as the study combined safety and security issues certain significant issues that could enhance our understanding of transport security were not explored. For example, while the study was able to assess the efficiency of traffic control and management agencies in the study area in terms of transport safety. However, almost nothing was reported on the efficiency of security agencies.

From the foregoing, it is clear that transport security is mostly influenced by such factors as gender, time of the day, road condition, travel mode, route condition, and human factors, among others. The aim of this study was to examine the extent to which these factors influence urban transport security in Osogbo, a state capital in Nigeria. The paper constitutes an attempt at bridging part of the existing gap in previous studies. It also examines the extent to which the findings of the previous studies were replicated in the city. A good understanding of the phenomenon of urban transport security in Osogbo would no doubt help in engendering efficient urban transport not only in the city but also in cities of comparable status.

\section{STUDY AREA}

Osogbo is the capital city of Osun State in Nigeria, a status it attained on the $27^{\text {th }}$ August, 1991. However, even before gaining its current status as a state capital, Osogbo had been an important centre of administration, trade and commerce for so many years. Osogbo is situated between latitudes $7.4^{\circ} \mathrm{N}$ and $8.0^{\circ} \mathrm{N}$, and between longitudes $4.3^{\circ} \mathrm{E}$ and $4.4^{\circ} \mathrm{E}$ of the Greenwich Meridian. The city seats the headquarters of both the Osogbo and Olorunda Local Government Areas. However, being a state capital, its territory is fast encroaching on a number of abutting local government areas. By road Osogbo is about 88 kilometres northeast of Ibadan the Oyo State capital, 100 kilometres south of Ilorin the Kwara State capital, and 115 kilometres northwest of Akure the Ondo State capital. By virtue of its regional centrality Osogbo is easily accessible from almost any part of the state. The city has a population of about 156694 people, according to the figures of the 2006 national population and housing census, with an annual growth rate of $3.5 \%$.

Even though a railway line traverses a part of the city, there is no intra-city train shuttle service. Also, despite the fact that River Osun, the non-navigable river after which the state is named, passes through Osogbo, the city is landlocked with no possibility of inland water transport. As such, Osogbo can be said to be a mono-modal city as road is the only operative mode of transport at present. There is no conventional mass transit system in Osogbo. Instead, two major types of paratransit systems are available in the city: korope (a small jitney that has the capacity of conveniently conveying about seven passengers), and okada (a popular local name for a commercial motorcycle). The koropes ply the major paved roads, while okadas are quite ubiquitous on both major and local roads.

The majority of residents in Osogbo travel by foot. However, walkways are conspicuously non-existent in the city. It is thus evident that provision is hardly ever made for pedestrians in transportation facilities investments in Osogbo. Also, there are no cyclist lanes in the city. A similar finding was made in Ilesa, a close by town, in an earlier study by Olojede, Yoade and Olufemi (2017). As such, vulnerable toad users (pedestrians and cyclists) share the transit corridors with motorists. To a large extent, on-street parking is controlled during working hours. However, the moment traffic workers close for the day, on-street parking becomes rampant. 


\section{SAMPLING PROCEDURE}

The sampling employed for this study was household based. Inasmuch as neither the number of houses nor the number of households in the city is available, the ward delineation popularly used for administrative convenience, pioneered by the Independent National Electoral Commission, was employed. According to this delineation, there are 19 wards in Osogbo. These 19 wards have been grouped by the town planning authorities in the two main local government areas in the town into the low-, medium- and high-density residential areas. There are six wards in either of the low- and high-density areas, while the medium-density area is made up of the remaining seven wards. From each group of wards, one of four $(25 \%)$ was randomly selected without replacement. Thus, two wards were selected from each of the residential density groups to give a total of six wards. From each ward, 75 households were randomly selected without replacement. Thus, 450 households were covered by the study. In each selected house a household was randomly conveniently picked and any available adult was surveyed. Of the 450 questionnaires administered, 432 were deemed usable by the study. This made the response rate to be $96.0 \%$.

\section{DATA ANALYSIS}

Data obtained from the study were analysed using percentages and the Relative Importance Index (RII), which was employed to analyse, operationally, three different variables with a view to measuring either their relative importance or frequency. These variables are the Relative Security Index (RSI), used to assess residents' perception of the relative security index of each transport mode; the Relative Efficiency Indicator Index (REII) used to assess respondents' perception of the relative efficiency of security agencies in the performance of their duties, and the Transit Crime Cause Relative Frequency Index (TCCRFI) used to assess respondents' perception of the relative frequency index of each cause of transit crime in the city. These parameters were selected based on a synthesis of indicators or factors found in the reviewed literature as those determining or influencing urban transport security.

The indices were computed following a process similar to that of RII. Similar uses of the RII are obtainable in such studies as Afon (2000 and 2006), Sambasivan and Soon (2006), Olojede, Daramola and Olufemi (2017), and Olojede, Yoade and Olufemi (2017). The respondents were asked to rate each of the variables of interest following the principle of the Likert Scale (Likert, 1961). In each case, the scale was from 1 to 5 in a descending order of significance (Very High, High, Average, Low, and Very Low) or frequency (Always, Very Often, Often, Rarely, Never), as the case may be. The Total Weight Value (TWV) for each variable was obtained through the summation of the product of the number of responses for each rating of the variable and the respective weight value. This is mathematically expressed as follows:

where:

$$
\mathrm{TWV}=\sum_{\mathrm{i}=\mathbb{1}}^{5} \mathrm{NiWi}
$$

$\mathrm{N}_{\mathrm{i}}=$ the number of respondents rating a particular variable, and

$\mathrm{W}_{\mathrm{i}}=$ the average weight value assigned to the variable by the respondents.

Thus, for example, the TCCRFI for each transit crime cause was computed by dividing the summation of the respondents' responses to each of the five ratings on the cause by the product of the highest weight attached to the value and the number of respondents. This is mathematically expressed as follows:

$$
\text { TCCRFI }=\frac{\text { TWV }}{\Sigma_{\mathrm{i}}^{5}=\mathrm{A} * \mathrm{Ni}}
$$

The closer the TCCRFI of a cause is to 5, the stronger the respondents' rating of such a cause as of transit crime in Osogbo, and the farther it is from 5 the weaker the rating of respondents of such a factor as a cause of transit crime in the study area. Other variables were measured in a similar way, and are interpreted as accordingly. 


\section{RESULTS AND DISCUSSION}

\section{Socio-economic Attributes of Respondents}

The socioeconomic attributes of the respondents are as presented in table 1.

Table 1. Socioeconomic Attributes of Respondents

(Data source: Author's Field Work, 2017)

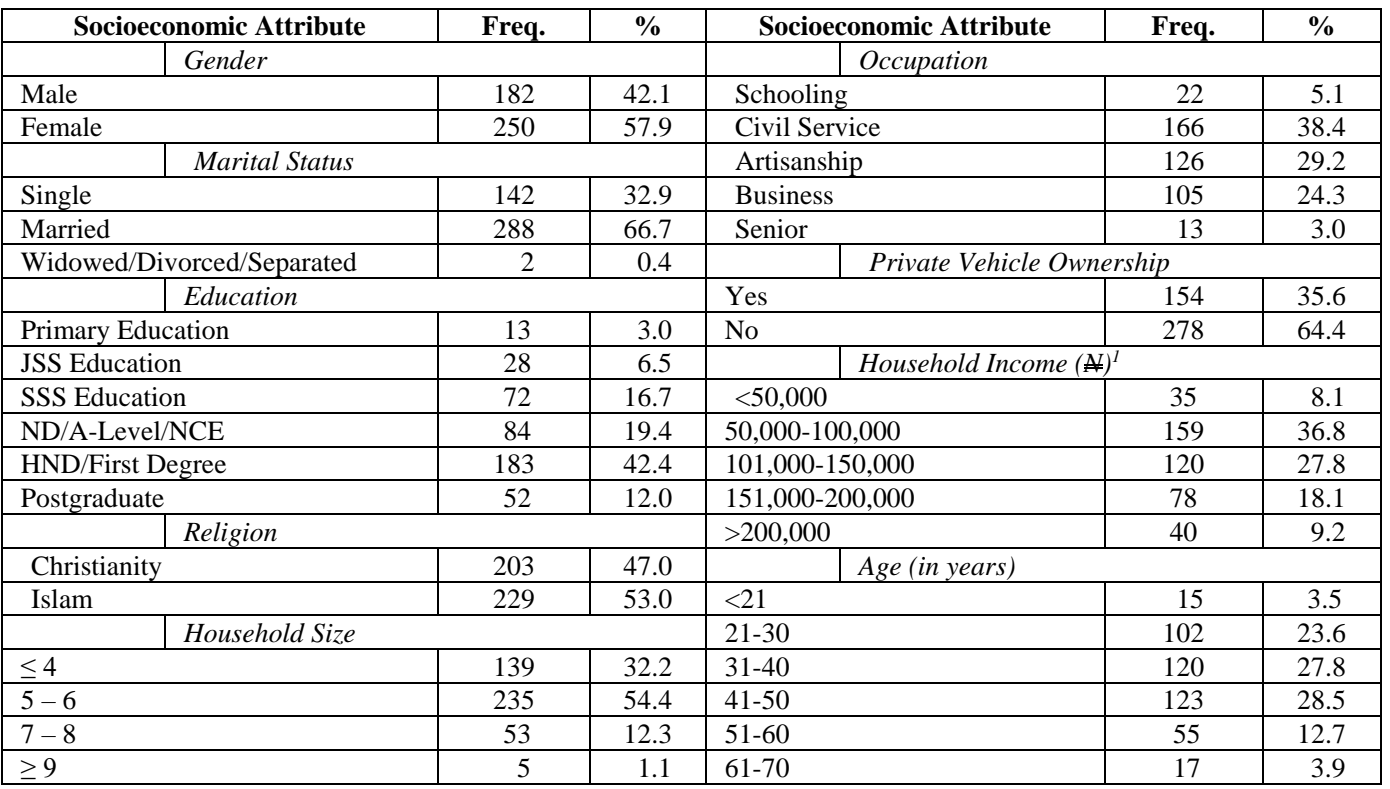

According to table $1,42.1 \%$ and $57.9 \%$ of the surveyed residents in the study area were male and female respectively. Information obtained on their marital status indicates that $32.9 \%$ were single, $66.7 \%$ were married, while the remaining $0.4 \%$ were widowed, divorced or separated. As for their education, $3.0 \%, 6.5 \%, 16.7 \%, 19.4 \%, 42.4 \%$ and $12.0 \%$ had a primary education, junior secondary education, senior secondary education, an A-Level equivalent, higher national diploma/first degree, and a postgraduate qualification respectively. A cursory look at the education background of the respondents is a pointer to the fact that they should be able to prioritise transport security and its ramifications.

Table 1 also provides an insight into the religious inclination of the respondents. According to the table, $47.0 \%$ of the respondents were Christians while $53.0 \%$ were of the Islamic faith. The occupational distribution of the respondents indicates that $5.1 \%$ were students, $38.4 \%$ were civil servants, $29.2 \%$ were artisans, $24.3 \%$ were engaged in business, while the remaining $3 \%$ were retirees/pensioners. Hence, it can be seen that there are more civil servants than any other category of workers in Osogbo. In addition, as presented in the table, $35.6 \%$ of the respondents had personal vehicles, while $64.4 \%$ did not have private vehicles. This shows that the majority of the respondents were captive riders as private vehicle ownership in the town is rather low.

Further analysis of table 1 reveals that the majority of the respondents' households belonged to the 50,000 - 100,000 naira monthly income category, just over 9\% earned over 200,000 naira per month, while $8.1 \%$ of the households earned less than 50,000 naira monthly. The age distribution of the respondents shows that there is almost a balanced spread. Except for $3.5 \%, 3.9 \%$ and $12.7 \%$ of the respondents who belonged to the less-than-21, 61-70 and 51-60 age brackets respectively, each of the other age groups had over $20 \%$ of the respondents.

\footnotetext{
${ }^{1}$ As of $10^{\text {th }}$ September, 2018, a US dollar (US\$1) exchanged for Nigerian 363.44 naira $\left(\mathbb{N}^{2} 363,44\right)$ officially.
} 


\section{Respondents' Latest Experience of Transit Crime in Osogbo}

Both the firsthand and secondhand latest experiences of the respondents as far as urban transit crime was concerned were as presented in table 2. In this context, a firsthand experience is one the respondent was a direct victim of, while a secondhand experience is one to which the respondent was a witness.

Table 2. Respondents' Latest Experience of Transit Crime (Data source: Author's Field Work, 2017)

\begin{tabular}{|l|l|c|c|c|c|}
\hline \multirow{2}{*}{ SN } & \multirow{2}{*}{ Type of Crime } & \multicolumn{4}{|c|}{ Latest Experience } \\
\cline { 3 - 5 } & & Over 6 months & Last 6 months & Last 3 months & Last 1 month \\
\hline 1. & Pickpocketing & $8.2 \%$ & $4.4 \%$ & $10.5 \%$ & $21.1 \%$ \\
\hline 2. & Armed Robbery & $3.2 \%$ & $1.9 \%$ & $2.4 \%$ & $1.1 \%$ \\
\hline 3. & Assault and Battery & $1.6 \%$ & $2.2 \%$ & $6.6 \%$ & $5.7 \%$ \\
\hline 4. & Rape/Sexual Harassment & $2.3 \%$ & $4.1 \%$ & $12.1 \%$ & $8.5 \%$ \\
\hline 5. & Kidnapping/Abduction & $9.4 \%$ & $6.6 \%$ & $5.5 \%$ & $2.3 \%$ \\
\hline 6. & Carjacking/car theft & $1.1 \%$ & $2.3 \%$ & $1.2 \%$ & $1.4 \%$ \\
\hline
\end{tabular}

According to table $2,8.2 \%, 3.2 \%, 1.6 \%, 2.3 \%, 9.4 \%$ and $1.1 \%$ of the respondents had witnessed or been victims of such transit crimes as pickpocketing, armed robbery, assault and battery, rape or sexual harassment, kidnapping or abduction, and carjacking or car theft respectively over the past six months; $4.4 \%, 1.9 \%, 2.2 \%, 4.1 \%, 6.6 \%$ and $2.3 \%$ had either witnessed or been victims of these transit crimes in the last six months; $10.5 \%, 2.4 \%, 6.6 \%$, $12.1 \%, 5.55$ and $1.2 \%$ had witnessed or been victims of transit crimes in the same order in the last three months; while $21.1 \%, 1.1 \%, 5.7 \%, 8.5 \%, 2.3 \%$ and $1.4 \%$ of them had witnessed or been victims of the transit crimes in the same order in the last one month.

Another look at the table reveals that pickpocketing was the transit crime experienced most in the last one month $(21.1 \%)$, rape or sexual harassment was the most experienced transit crime in the last three months (12.1\%), kidnapping was the transit crime experienced most in both the last six months $(6.6 \%)$ and over six months prior to the time of the survey $(9.4 \%)$. Moreover, armed robbery was the transit crime least experienced in both the last one month $(1.1 \%)$ and the last six months $(1.9 \%)$, while carjacking or car theft was the least experienced transit crime both in the last three months $(1.2 \%)$ and over six months prior to the time of the survey $(1.1 \%)$. There was no report of such transit crimes as fare evasion, murder, terrorism, and vandalism over the period among the respondents. Thus, it is obvious that these categories of transit crime are quite rare in the study area.

Further, the results of Chi-square tests carried out shows that there was a significant relationship between transit crime experience and such socioeconomic characteristics of Osogbo residents as age $\left(\chi^{2}=32.713, \mathrm{p}<0.001\right)$, gender $\left(\chi^{2}=17.401, \mathrm{p}=0.001\right)$, household income $\left(\chi^{2}\right.$ $=20.235, \mathrm{p}=0.002)$, private vehicle ownership $\left(\chi^{2}=80.709, \mathrm{p}<0.001\right)$, and occupation $\left(\chi^{2}=\right.$ $27.174, \mathrm{p}<0.001)$. However, no significant relationship was found between transit crime experience and household size $\left(\chi^{2}=13.329, \mathrm{p}=0.071\right)$, religion $\left(\chi^{2}=24.717, \mathrm{p}=0.101\right)$, education $\left(\chi^{2}=35.115, \mathrm{p}=0.093\right)$, and the marital status $\left(\chi^{2}=29.575, \mathrm{p}=0.173\right)$ of the residents of the city.

\section{Transit Crime by Mode in Osogbo}

In table 3, an attempt is made to categorise transit crime by mode in Osogbo. Information obtained on types of crime usually associated with different transport modes in the study area is presented. Respondents were asked to rate the transit crime vulnerability by transport mode in the city. According to the opinions of the respondents as presented in the table, korope passengers were the most vulnerable group of travellers to both pickpocketing and assault and battery, private car occupants were the most vulnerable group to armed robbery, while okada passengers were the most vulnerable group to both rape or sexual harassment and kidnapping or abduction in Osogbo. 
Table 3. Transit Crime Vulnerability by Mode

(Data source: Author's Field Work, 2017)

\begin{tabular}{|c|c|c|c|c|c|c|c|}
\hline \multirow[b]{2}{*}{ SN } & \multirow[b]{2}{*}{ Type of Crime } & \multicolumn{6}{|c|}{ Mode } \\
\hline & & $\stackrel{\overrightarrow{8}}{\circ}$ & $\begin{array}{l}\frac{\pi}{5} \\
\frac{\pi}{0}\end{array}$ & 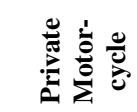 & : & 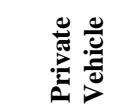 & 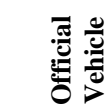 \\
\hline 1. & Pickpocketing & $8.3 \%$ & $6.4 \%$ & $0.3 \%$ & $29.7 \%$ & $0.7 \%$ & $0.0 \%$ \\
\hline 2. & Armed Robbery & $1.4 \%$ & $37.9 \%$ & $3.7 \%$ & $6.1 \%$ & $11.8 \%$ & $8.8 \%$ \\
\hline 3. & Assault and Battery & $7.4 \%$ & $7.8 \%$ & $2.1 \%$ & $9.8 \%$ & $0.6 \%$ & $1.1 \%$ \\
\hline 4. & Rape/Sexual Harassment & $6.5 \%$ & $18.1 \%$ & $0.0 \%$ & $17.3 \%$ & $1.2 \%$ & $0.8 \%$ \\
\hline 5. & Kidnapping/Abduction & $0.8 \%$ & $14.6 \%$ & $1.8 \%$ & $5.3 \%$ & $11.3 \%$ & $9.5 \%$ \\
\hline
\end{tabular}

Further, the opinion poll has it that occupants of official vehicles were not vulnerable to pickpocketing; pedestrians were the group of travellers least vulnerable to both armed robbery and kidnapping or abduction; private car occupants were the least vulnerable group to assault and battery; while private motorcyclists/passengers were not in any way vulnerable to rape or sexual harassment. A closer look at the table reveals that all in all okada passengers are evidently the most vulnerable group of travellers in Osogbo as their vulnerability index to any of the transit crimes is either the highest or one of the highest. Conversely, occupants of official vehicles were deemed the most secure group of travellers as their vulnerability index to any of the transit crimes is either the lowest or one of the lowest. Occupants of private vehicles came after those of official vehicles in this regard.

The foregoing results have shown that no group of travellers was essentially predominantly vulnerable to all the categories of transit crime. However, it has been shown that passengers of different modes were vulnerable to different categories of transit crime. This compares favourably with the finding of Olojede, Daramola and Olufemi (2017). However, the finding on Ilesa revealed that pedestrians were the most vulnerable group of travellers, which happened not to be the case in Osogbo as found by this study.

\section{Causes of Transit Crime in Osogbo}

The ranking of the causes of transit crimes in Osogbo in order of frequency as rated by respondents is as shown in table 4 .

Table 4. Relative Frequency of Transit Crime Causes in Osogbo

(Data source: Author's Field Work, 2017)

\begin{tabular}{|c|c|c|c|c|c|}
\hline SN & Cause & $\mathbf{N}$ & TWV & TCCRFI & Rank \\
\hline 1. & Economic hardship/recession/poverty & 432 & 2035 & 4.63 & 2 \\
\hline 2. & Joblessness/unemployment & 419 & 1743 & 4.16 & 8 \\
\hline 3. & Substance abuse/Illicit drug use & 432 & 1896 & 4.39 & 5 \\
\hline 4. & Poor policing/under-policing & 432 & 2000 & 4.71 & 1 \\
\hline 5. & Absence of CCTV and streetlights & 412 & 1874 & 4.55 & 4 \\
\hline 6. & Poor street system/urban planning & 422 & 1924 & 4.56 & 3 \\
\hline 7. & TV violence & 431 & 1810 & 4.20 & 7 \\
\hline 8. & Peer group influence & 430 & 1874 & 4.36 & 6 \\
\hline 9. & Family breakdown & 426 & 1695 & 3.98 & 9 \\
\hline
\end{tabular}

As shown in table 4, poor policing/under-policing was seen as the strongest cause of transit crime in Osogbo. This was followed by economic hardship/recession/poverty. Poor street system/urban planning and the absence of closed-circuit television (CCTV) ranked third and fourth respectively, while substance abuse/illicit drug use and peer group influence ranked fifth and sixth respectively. TV violence ranked seventh, while joblessness/unemployment and family breakdown were ranked the eighth and ninth strongest causes of transit crime in Osogbo. 


\section{Transit Security Indices of Urban Transport Modes in Osogbo}

In table 5, the Relative Security Index (RSI) was employed to assess the security of urban travellers in Osogbo.

Table 5. Security Indices of Urban Transport Modes in Osogbo (Data source: Author's Field Work, 2017)

\begin{tabular}{|c|c|c|c|c|}
\hline \multirow{2}{*}{ Mode } & \multicolumn{4}{|c|}{ Security Index } \\
\hline & $\mathbf{N}$ & TWV & RSI & Rank \\
\hline Foot & 430 & 1716 & 3.99 & 5 \\
\hline Ọkada & 432 & 1365 & 3.16 & 6 \\
\hline Private Motorcycle & 432 & 1931 & 4.47 & 3 \\
\hline Korope & 431 & 1784 & 4.14 & 4 \\
\hline Private Vehicle & 432 & 2026 & 4.69 & 2 \\
\hline Official Vehicle & 429 & 2094 & 4.88 & 1 \\
\hline
\end{tabular}

According to table 5, as far as transit crime was concerned in Osogbo, those who travelled in official vehicles were deemed the most secure. Next to this group were the occupiers of private vehicles. Okada passengers were seen as the group with the least level of transport security in the study area.

\section{Temporal Dimensions to the Occurrence of Transit Crime in Osogbo}

The temporal dimension to transit crime in Osogbo was examined.

The result is as shown in table 6.

Table 6. Temporal Dimensions to Transit Crime in Osogbo (Data source: Author's Field Work, 2017)

\begin{tabular}{|l|l|c|c|c|c|}
\hline \multirow{2}{*}{ SN } & \multirow{2}{*}{ Type of Crime } & \multicolumn{4}{|c|}{ Time Most Rampant } \\
\cline { 3 - 6 } & & Morning & Afternoon & Evening & Night \\
\hline 1. & Pickpocketing & $45.6 \%$ & $42.3 \%$ & $52.5 \%$ & $2.1 \%$ \\
\hline 2. & Armed Robbery & $13.2 \%$ & $21.4 \%$ & $2.4 \%$ & $3.5 \%$ \\
\hline 3. & Assault and Battery & $3.2 \%$ & $5.3 \%$ & $4.6 \%$ & $11.3 \%$ \\
\hline 4. & Rape/Sexual Harassment & $0.2 \%$ & $0.7 \%$ & $18.3 \%$ & $9.5 \%$ \\
\hline 5. & Kidnapping/Abduction & $2.4 \%$ & $26.6 \%$ & $45.5 \%$ & $4.3 \%$ \\
\hline 6. & Carjacking/car theft & $6.1 \%$ & $14.7 \%$ & $17.6 \%$ & $13.1 \%$ \\
\hline
\end{tabular}

According to table $6,52.5 \%$ of the respondents opined that pickpocketing was most rampant in the evening (52.5\%), armed robbery was said to be the most rampant in the afternoon (21.4\%), assault and battery was most rampant at night (11.3\%), rape or sexual harassment was most rampant in the evening (18.3\%), kidnapping or abduction was most rampant in the evening $(45.5 \%)$, while carjacking or car theft was most rampant in the evening (17.6\%). Further analysis reveals that pickpocketing was the most rampant transit crime in the morning (45.6\%), afternoon (42.3\%) and evening (52.5\%), while carjacking or car theft was the most rampant transit crime at night.

\section{TRAFFIC CONTROL AND MANAGEMENT IN OSOGBO}

Policing is a very germane aspect of security. In the context of this study, policing goes beyond the security services provided by the conventional police force. Rather, it encompasses the security services provided by all the security agencies in Osogbo. The security agencies as conceived in this study are the Nigeria Police Force, the Nigeria Security and Civil Defence Corps, and the registered vigilante groups. An assessment was made of the efficiency of these security agencies in Osogbo. Respondents were asked to rate some indicators to measure the level of the efficiency of these bodies from 1 to 5 . These indicators are made up of the six major manifest functions of the agencies. The indicators employed were: adequacy of transit security provision; 
dignity, integrity, respectability, reliability and trustworthiness; transit crime prevention or proaction; responsiveness to reports of crime; law enforcement/making criminals face the full course of law; and the ability to instil confidence when present. The respondents' assessment of the efficiency of the security agencies is as summarised in table 7.

Table 7. Efficiency Rating of Security Agencies in Osogbo

(Data source: Author's Field Work, 2017)

\begin{tabular}{|l|c|c|c|c|}
\hline \multicolumn{1}{|c|}{ Indicator } & N & TWV & REII & Rank \\
\hline Adequacy of transit security provision & 432 & 968 & 2.24 & 2 \\
\hline Dignity, integrity, respectability, reliability and trustworthiness & 431 & 901 & 2.09 & 3 \\
\hline Transit crime prevention or proaction & 430 & 413 & 0.96 & 4 \\
\hline Responsiveness to reports of crime & 432 & 276 & 0.64 & 6 \\
\hline Law enforcement/making criminals face the full course of law & 431 & 388 & 0.90 & 5 \\
\hline Ability to instil confidence when present & 432 & 1214 & 2.81 & 1 \\
\hline
\end{tabular}

According to table 7 , the respondents did not have a high opinion of the security agencies as far as transit security provision was concerned in the city. For instance, the indicator with the highest index, the ability to instil confidence when present, has a value of 2.81 . Responsiveness to reports of crime has an index that is as low as 0.64. All these six indices say a lot about how the respondents viewed the transit service provision of the security agencies in Osogbo. In other words, the respondents rated security agencies in Osogbo low on their transit security provision.

\section{CONCLUSIONS, IMPLICATIONS AND RECOMMENDATIONS}

This study has explored several types or categories of transit crimes in Osogbo. The findings of the study, as discussed in the foregoing section, are to a reasonable extent in consonance with what have been established by several previous studies in the literature of urban transport security. In summary, the study found that several conventional transit crimes were perpetrated in the study area as earlier found by Odufuwa (2012a). However, the study provides no empirical evidence to support the prevalence of some transit crimes in Osogbo. Such transit crimes include fare evasion, murder, terrorism, and vandalism. The study also reveals that transit crimes in Osogbo have a relationship with some socioeconomic characteristics, and that there is time dimension to them. These corroborate the findings of Odufuwa (2012b), Ajayi and Ajayi (2014), and Uittenbogaard (2014). It was also found by this study that the perception of urban transport security varies by mode, as earlier established by Olojede, Daramola and Olufemi (2017).

Further, the study uncovered several causes of transit crime in Osogbo, determined the security indices of the intra-urban transport modes in the city, and assessed the efficiency of security agencies in the city. More importantly, this study has given us important insights into understanding the security issues in urban transportation in Osogbo. The implications of the findings of this study are many. They cut across physical planning, transport planning, and urban policing, among other institutional interests. Consequently, measures should be put in place by concerned stakeholders to engender a secure transport environment in Osogbo. To this end, the following policy recommendations are proffered.

First, a holistic and systemic overhaul of the transport system in Osogbo should be accorded topmost priority. Transport facilities in the city should be improved on with nonmotorised transport and mass transit as integral parts. Hitherto these have been practically nonexistent in Osogbo. Much of the security threats associated with okada could be prevented by mass transit, and captive riders would feel more secure. In addition, the proscription of okada operation in the city should be conscientiously contemplated. If the road infrastructure of the city is overhauled, the need for okada would be undercut despite its present seeming indispensability. Also, the provision of walkways, streetlights, and CCTV would go a long way in enhancing the security of vulnerable travellers in the city. Moreover, with a view to winning back the confidence of travellers in the city, security agencies in Osogbo should actually outdo themselves by 
significantly improving on their services. As a way of achieving this is, they should consider the joint task security force option. This would go a long way in ensuring a secure urban transport milieu in Osogbo.

\section{REFERENCES}

Afon, A. (2000). Use of Residents Environment Quality Indicator (EQI) Data in a residential Housing improvement. In Effective Housing in the $21^{\text {st }}$ century, Nigeria. The Environmental Forum, FUTA (pp. 115-122).

Afon, A.O. (2006). The use of residents' satisfaction index in selective rehabilitation of urban core residential areas in developing countries. International Review for Environmental Strategies, 6(1): 137-152.

Ajayi, D.D., \& Ajayi, A.P. (2014). Trend analysis of crime incidences and crime vulnerability differentials on urban transport facilities in Ibadan. Journal of Intelligent Transportation and Urban Planning, 2(2), 85-97.

Couto, M.T., Lawoko, S., \& Svanström, L. (2009). Violence against drivers and conductors in the road passenger transport sector in Maputo, Mozambique. African Safety Promotion: A Journal of Injury and Violence Prevention, 7(2): 17-36.

Klima, N. (2011). The goods transport network's vulnerability to crime: opportunities and control weaknesses. European Journal on Criminal Policy and Research, 17(3): 203-219.

Korver, W., Stemerding, M., Van Egmond, P., \& Wefering, F. (2012). CIVITAS Guide for The Urban Transport Professionals: Results and lessons of long-term evaluation of the CIVITAS initiative. CIVITAS, Delft.

Lauer, J. (2005). Driven to extremes: Fear of crime and the rise of the sport utility vehicle in the United States. Crime, Media, Culture, 1(2): 149-168.

Likert R. (1961). New Patterns of Management. McGraw-Hill, New York, USA.

Litman T. (2014). Safer Than You Think! Revising the Transit Safety Narrative, Victoria Transport Policy Institute, www.vtpi.org, accessed 25.08.2018.

Mercier-Handisyde P. (2009). Urban Transport Research in the European Union, A paper presented at a workshop held on Security of Mass Transportation, Berlin, March 18, https://www.sifo.de/files/WS_MT_Mercier-Handisyde.pdf, accessed 25.08.2018.

Odufuwa, B.O. (2012a). Passengers' Perception of the Effects of Crime Incidents on Patronage of Public Transport in a Nigerian Megacity: A Case Study of Lagos Metropolis. Journal of Environmental Management and Safety, 3(2): 170-187.

Odufuwa, B.O. (2012b). Gender and Safety in Public Transportation: An Exploration Study in Lagos Metropolis, Nigeria, Institute for Housing and Urban Development Studies, Erasmus University Rotterdam, http://hdl.handle.net/2105/12208, accessed 24.08.2018.

Olojede, O., Daramola, O., Olufemi, B. (2017). Metropolitan Transport Safety and Security: An African Experience. Journal of Transportation Safety \& Security, 9(4): 383-402.

Olojede, O., Yoade, A., Olufemi, B. (2017). Determinants of Walking As an Active Travel Mode in a Nigerian City. Journal of Transport \& Health, 6: 327-334.

Omidiji, A.A., Ibitoye, S.A. (2010). Crime and Road Crashes Prevention in Public Transportation System in Nigeria: The Case Study of Kwara, Kogi and Ekiti States, $24^{\text {th }}$ ARRB Conference-Building on 50 Years of Road and Transport Research. Melbourne, Australia.

Sambasivan, M., Soon, Y.W. (2006). Causes and Effects of Delays in Malaysian Construction Industry. International Journal of Project Management, 25: 517-526.

Stanley, J. (2015), Prevention of Aggression to Bus Drivers, A Report for Bus Association Victoria, Stanley \& Co. Pty Ltd, February, http://www.busvic.asn.au/images/uploads/links/Prevention_of_Aggression_to_Bus_Drivers.pdf, accessed 27.05.2018.

Uittenbogaard, C.A. (2014). Crime Clusters and Safety in Underground Stations, unpublished PhD Thesis, Department of Real Estate and Construction, School of Architecture and the Built Environment, KTH Royal Institute of Technology.

U. S. Department of Labor Occupational Safety and Health Administration (2000), Risk Factors and Protective Measures for Taxi and Livery Drivers (online), https://www.osha.gov/OSHAFacts/taxi-livery-drivers.pdf, accessed 27.05.2018.

Submitted:

July 03, 2018
Revised:

November 05, 2018
Accepted and published online January 23, 2019 